\title{
II. Red List of Biotopes and Biotope Complexes of the Wadden Sea Area*
}

\author{
CONTRIBUTORS: \\ Germany: A. Ssymank \\ The Netherlands: N. Dankers
}

\section{INTRODUCTION}

The Red List of Biotopes of the Wadden Sea Area $“$ is based on the existing lists for Germany and The Netherlands.

The development of a red list for The Netherlands (Dankers \& Wolff, 1994) was commissioned by the National Reference Centre (IKC) of the Department for Nature Management of the Netherlands Ministry of Agriculture, Nature Management, and Fisheries. The list has been prepared by N. Dankers and W.J. Wolff of the Institute for Forestry and Nature Research (IBN - DLO). The habitat map of Dijkema (1989) formed the starting point of the description of biotopes. Local knowledge and discussions with specialists were used to categorize the biotopes and transition zones.

The German list of biotopes for the Wadden Sea and coastal regions constitutes a part of a red list of all German biotopes (Riecken et al., 1994). It has been elaborated by the Federal Agency for Nature Conservation (Bundesamt für Naturschutz) within the Department for Biotope Protection and Landscape Ecology. The results are based on own expertise and an extensive consultation of scientific experts of the Bundesländer and of universities.

Both national lists have been based on existing data; no new supplementary research has been carried out in the field for this purpose.

\section{General framework of a Red List for Biotopes}

For a dynamic system like the Wadden Sea, it may be very useful to develop a Red List for biotopes. A great variety of biotope types can be recognized, and limited taxono-

- This list forms part of the Report on the RED LISTS OF BIOTOPES, FLORA AND FAUNA OF THE TRILATERAL WADDEN SEA AREA. Although Denmark could not contribute to this list due to lack of data on the situation of biotopes and biotope complexes, Denmark at this stage agrees to the overall status of threat.

* While in the literature the terms habitat and biotope are often used as synonyms, the scientific term "habitat" means the place where a distinct species is living. "Biotope "(types) are "small" ecosystems with defined biotic and abiotic conditions. The scope of the trilateral Wadden Sea Conference was to elaborate a trilateral red list of biotopes. For definitions see chapter 'Spatial units'. 
mic knowledge is required. Protection of biotopes will in most cases provide the right conditions for dependent species to survive. Species protection alone is very difficult in many cases, because of high fluctuations in the populations from year to year or because of migrations. If it can be made clear which biotope types are under pressure, these can be placed on a Red List. Often it will also be clear which impacts are responsible for the deterioration of a Red List biotope, and management can act accordingly. In this way, known, but also unknown Red-List-species will be simultaneously protected.

A Red List of biotopes serves many purposes, as for example listed in the general introduction, but focussing especially on:

- help for the implementation of international conventions and Directives of the European Union (for example Ramsar Convention, Habitats Directive 92/43/EEC of the EU) as well as national laws that include aspects of biotopes protection

- introducing a more holistic landscape approach in nature conservation, which goes beyond pure species-oriented conservation strategies.

Development of a Red List for biotopes confronts us with some problems which do not occur when setting up a list for species. Without a clear definition for a biotope type it will prove difficult to make a list of threatened biotopes. When observed in great detail, each biotope is different and therefore unique. When defined too broadly very few biotope types will fulfil the requirements for inclusion in a Red List. Another problem is the fact that biotopes are in a dynamic state. They do not become suddenly extinct like a species, but they usually change their species composition and structural appearance slowly when the surrounding conditions change. Sometimes they show a cyclic development. In a 'complete' ecosystem all stages of the cycle should be present when viewed over a number of years. The length of this time span is dependent on the cycle-time and the number of successional stages. A decrease of one particular stage does not have to mean that the biotope is threatened if earlier stages are allowed to develop. This means that too strong 'protection' of one particular biotope type, being part of a succession series, may cause problems in the long run.

The properties of threat (see criteria system), I Loss in area and, especially, II Loss in quality can only be quantified if references are described. References can be described in three ways:

1. In a geographically similar area, a comparable system can be studied.

2. A historical situation can give an idea how a biotope can look like, taking into account development and natural fluctuations. For different variables, examples from different years may have to be taken, or sometimes means over a number of years are a better option.

3. On the basis of theoretical considerations, based on ecological knowledge.

In practice all three methods are used together.

From a nature management point of view the more important biotope types in the Wadden Sea area are those which are formed and maintained by an interplay of physical and biological processes. If only physical processes are important, the regeneration ability generally will be good, unless the physical processes are prevented from acting.

In the North Sea, the Wadden Sea and in the estuaries, tides and waves are responsible for the mixing of the water column, the transport of sediment and the transport of nutrients and organisms. Light and temperature are responsible for the primary production. 
In the estuarine and coastal regions the tidal amplitude is responsible for the largescale morphology of the coastal area. Sandy coasts with a small tidal amplitude develop into a coastline with lagoons. Coasts with medium tidal amplitude develop into a system of barrier islands with intertidal flats between the islands and the mainland. Areas with a large tidal amplitude form an open coast with intertidal sand banks. The tidal currents together with wind and waves are responsible for the maintenance of gullies and tidal flats. Wind, and the availability of sand are the primary factors in dune and island formation.

In the tidal areas along the coast several characteristic structures have developed. A Wadden Sea system is characterized by complete gully systems. That means, a tidal inlet, ebb and flood systems and main channels, which branch into small gullies and creeks in sandy or silty areas or saltmarshes. Within a Wadden Sea system there is a diversity of tidal flats with sediment of different silt content and different exposure times.

In an interplay of physical and biological processes, saltmarshes and dunes are formed. Erosion and sedimentation processes cause small islands to move in the direction of sand transport. Some typical structures especially in the marine environment have a biogenic origin such as oyster and mussel beds, reefs of tube building polychaetes or eelgrass fields.

The area near the tidal inlets is very dynamic. Sand banks in the tidal inlet migrate in a clockwise direction and cross over to the next island. The sand moves along the island like a wave. The tip of the island shows cyclic growth and erosion, depending on the availability of sand. On some high sand flats, vegetated dunes may develop. Occasionally these islands move in the direction of the sand transport, and may eventually disappear.

Although the system as a whole will contain the major elements of marine or estuarine systems, any specific part of the system may not always contain all of these elements.

It is essential to determine which elements of the ecosystem must be regarded as 'critical capital'. Critical capital are elements which are not replaced when destroyed. These can be processes, geomorphological or biogenic structures, species, or elements like scenic beauty.

In the following section a number of biotopes will be described briefly. These biotopes have been selected on the basis of the most important physical processes which were responsible for their formation. As important Red List-processes we consider horizontal and vertical tides, wind, waves, primary production, grazing, predation and breakdown of organic matter. This does not mean that all biotopes will occur if all of these processes occur in a region.

If available, some aspects relating to quantity, quality and possibilities for regeneration will be described, as well as the significance for some species which are considered important. Often these parameters can only be quantified properly if references are available. For several typical Wadden Sea biotopes, reference areas have been suggested in the IKC-report by van Leerdam et al. (1993). Further studies are needed to develop methods to describe and quantify the intrinsic values of biotopes, and to implement this methodology in the suggested biotopes.

A general overview of coastal biotopes is given in the habitat atlas of Dijkema (1989). Biotopes are also listed on the suggested German Red List (Riecken et al., 1994). It is mainly based on characteristics of the substrate. The advantage is that it is easy to map, but the relation with physical and biological processes is not always clear. It is therefore 
not easy to evaluate the level of threat which would justify that the biotope type be on a Red List. The German list therefore contains clear biotopes, whereas the national list of The Netherlands often contains biotope-complexes. When attempts are made at mapping, it seems wise to follow the German approach.

\section{Delimitation of the area}

The area investigated for the preparation of the Red List of Biotopes has been trilaterally agreed on at the 1st meeting of the Working Group in November 1993 (for details see chapter General Introduction). The $20 \mathrm{~m}$ isobath line seaward delimitation corresponds mainly to a water depth where the photic conditions are still sufficient for benthic macrophytes under favorable water conditions without pollutants. At the same time this zone constitutes a part of the coastal system with sand transport by currents and waves.

\section{Elaborating a trilateral approach}

The German list is based on biotopes as they can be recognized in the field. The biotopes are therefore easy to map, but because of interrelations between biotopes, more complex and specific combinations of the biotope types are needed in some cases as management units. The German Red Data book gives only a very rough approach to these biotope complexes.

The Dutch list is based on natural processes which form and maintain recognizable biotope types. These biotope types often form clear management units, but according to the German system they often should be considered as biotope complexes. Although some of these complexes may not contain threatened biotopes or species, the complex as a whole may be very characteristic for the Wadden Sea, and threatened as a whole.

In part I of the trilateral list, biotope complexes are listed which might be considered functional landscape units. Examples are migrating islands, sheitered bays, estuaries, complete gully systems and bordering tidal flats, unprotected tips of islands, saltmarshes, transition zones etc. These landscape units may contain all or a large number of the threatened biotopes listed later, and should be managed as a whole. The biggest threats to these complexes that have led to a loss of area are coastal protection, urbanization, development and maintenance of shipping routes. The quality of these units may be affected by disturbance (tourism, military exercises, management services).

In part II of this list, recognizable biotope types have been listed. The structure of the German list has been followed, and the corresponding biotope types of the Dutch list are indicated.

For Denmark, at the moment, it was not possible to get sufficient data that could be included in the trilateral approach for the red list of biotopes. Thus the trilateral overall assessment of threat is preliminary in some cases, as far as possible changes might occur after investigating the situation in the Wadden Sea area of Denmark. Nevertheless, in some cases, especially for biotope types which are characterized by certain well defined vegetation types, the already existing trilateral red list on plant communities of Westhoff et al. (1993) gives a good indication of the overall status of threat for the whole Wadden Sea area. 


\section{Criteria system}

The assessment of threat and the evaluation of the regeneration ability follows the German proposal (Blab et al., 1995) that has been worked out by the Federal Agency for Nature Conservation (Bundesamt für Naturschutz). Detailed definitions of all criteria used can be found in this paper. The system is based on two properties of threat, supplemented by an assessment of regeneration ability. Criteria like international importance or species dependent on the biotope type have not been used.

The properties are:

I Threatened by destruction (Loss of area).

II Threatened by qualitative changes (Loss of quality).

III Assessment of regeneration ability.

For each property an attempt is made to use similar categories for the criteria as in the approaches for the Red List for species but adapted to the needs of assessment of biotopes. The following categories according to Blab et al. (1995; for full definitions see this paper) are used:

I. Loss of area, threatened by direct destruction (DE):

0 Completely destroyed (extinct).

1 Threatened by complete destruction without proper protection or management (critical).

2 Heavily endangered, indicated by heavy decline of area in nearly the whole Wadden Sea region or extinction in several subregions.

3 Endangered, indicated by a general decline or locally extinct at numerous sites.

P Potentially endangered: Typical for a biotope only occurring within a confined area which is not threatened as long as nothing goes wrong.

* Presumably not endangered at present.

II. Loss of quality, threatened by qualitative changes (QU)

This is based on general degradation, such as decrease of biodiversity, especially the loss of typical species, or the destructions of specific variants. The quality can relate to abiotic conditions, structure, typical set of species, interactions of species etc.

0 Completely destroyed. Typical or natural variants have disappeared.

1 Threatened by complete destruction, indicated by the fact that the quality is negatively changed in the whole range of distribution within the Wadden Sea so that typical variants are threatened by complete destruction.

2 Heavily endangered, indicated by a decline of typical variants, or the extinction of variants in subregions.

3 Endangered, when a decline of typical variants over a broad range can be stated, or typical variants became extinct at numerous sites.

* Not endangered.

\section{Regeneration ability (RE)}

In a dynamic system like the Wadden Sea, it is often possible for a biotope type to regenerate. Therefore, it is important to include this property when assessing whether a biotope has to be included in a Red List. The regeneration ability is a characteristic fea- 
ture of a certain biotope type, but the regeneration process itself depends very much on the local and regional situation, including the distances to cover by recolonizing species etc. For property III (regeneration ability, RE) the following criteria have been used:

N Regeneration impossible.

K Regeneration hardly possible (more than 150 years).

$S$ Regeneration difficult (15-150 years).

B Regeneration conditionally possible (less than 15 years under favorable conditions; certain typical species might nevertheless need longer time).

$\mathbf{X}$ Classification not meaningful (spreading introduced or highly anthropogenic types, succession or dynamic stages of a very short occurrence).

The criteria I and II were merged to one overall evaluation, which has at least the same level of the highest rank given.

\section{Spatial units used}

The Red List of Biotopes and Biotope Complexes of the Trilateral Wadden Sea Area is based on the following definitions of spatial units that are classified as: PART I: Threatened biotope complexes and complex regional landscape units; PART II: Threatened biotope types.

Types of biotope complexes: characteristic, constant mosaic or spatial distribution of certain biotope types. This includes zonation of biotopes along an ecological gradient (e.g. gradient of humidity), and anthropogenous distribution types caused by the historical and cultural development of a certain landscape." (Blab et al., 1995).

Type of biotope: idealized type, derived from similar biotopes in the field, having specific ecological, unique and more or less constant environmental conditions for animal and plant life... Biotopes constitute the spatial compound of an ecosystem. " (Blab et al., 1995). Biotope types have a certain minimum size, which enables mapping in the field.

Following a hierarchical concept, also biotope complexes are often grouped together in a very specific way. These larger regional landscape units (see proposals of the IUCNCESP Working Group on Red lists for landscapes) have been placed at the beginning of the red list of biotope complexes, if they are threatened and if they play an important role under functional aspects and in the management of whole dynamic landscape systems.

Small microsystems or biotope elements with more or less specific environmental conditions like e.g. a stone covered with algae in a sandy benthic biotope of the Wadden Sea, or a decaying plant, are not included in the trilateral list. They may occur in different biotope types and in very characteristic combinations, but as they cannot be treated as separate management units they are omitted. Important characteristic biotope elements are mentioned in the definitions of the national contributions (Riecken et al., 1994; Dankers \& Wolff, unpubl.). 


\section{SHORT DESCRIPTIONS}

\section{PART I: Biotope complexes and larger functional landscape units}

\section{Landscape complexes:}

Migrating islands: Most Wadden Sea islands used to migrate, either in the direction of the sand drift, or inland with the rising sea level. The inhabited islands are now kept in place by coastal protection measures. Only the uninhabited tips of these islands still show the characteristics of migrating islands. In the Dutch Wadden Sea there are two examples of migrating islands left (Rottumerplaat, Rottumeroog). The quality of these two must be considered low because of conservative coastal and dune management practices. Restoration is relatively easy, but is partly hampered by the occurrence of large quantities of rubble, rock and concrete which were used in the past for coastal protection. In the German Wadden Sea several examples of small islands occur that recently developed and are still without any coastal protection or human settlement (for example: Trischen). They usually have a typical mosaic of young dynamic biotope types, presenting a nowadays very rare complex functional system with very high nature conservation value.

Major biotope complexes: A3, C1, C3.

Sheltered bays: Sheltered bays with their great variety of biotopes used to be an integral part of the Wadden Sea. Since medieval times the surface area of the bays has decreased due to embankments. A distinction should be made between bays with and without freshwater inflow. The Dollart and Lauwerszee are examples of bays with freshwater inflow, the German Jadebusen an example of a bay without freshwater inflow. In The Netherlands only the Dollart is left. The quality of the bay is still impaired by pollution and large-scale dredging activities in the seaward part. Restoration is in principle possible, but will cause loss of invested capital. Three areas with relative shelter which might be called bays are the bights of Terschelling, Vlieland and the Balgzand.

Major biotope complexes: A2, A3, C1.

Estuaries: An estuary is defined as a semi-enclosed part of coastal waters in which there is a recognizable tide with a distinct inflow of freshwater by a river, causing a gradient from fresh to saline water. The boundary of the estuary is drawn as far as the brackish influence is recognizable, yet tidal freshwater biotopes may go much further inland. In the Dutch Wadden Sea the Dollard, Lauwerszee and Zuiderzee used to be estuaries. At present only the Dollard still has estuarine characteristics. The salinity gradient is caused by the runoff of the German river Ems and the discharge of the Dutch Westerwoldse Aa. The Ems shows a gradient up to freshwater, but the Westerwoldse Aa discharges through a sluice at low tide. It can therefore be concluded that estuaries are extinct in the Dutch Wadden Sea. The remaining estuarine characteristics of the Dollard have been of low quality in the past because of severe organic pollution. The situation has improved recently. Restoration of the estuarine situation in the Dutch Wadden Sea will only be possible after large-scale engineering activities and is not considered realistic. In some areas it may be possible to restore some of the characteristic conditions and give room for the species that are dependent on these characteristics. In Germany, the estuaries of the river Elbe and Weser are the most important ones, still having in some small parts more or less natural biotope types. Nevertheless, most of the embankments 
are heavily degraded or destroyed by industry and housing estates and both water pollution and transport cause serious threats.

Major biotope complexes: A2, A3, C1, C3.

\section{Biotope complexes}

A2 Natural coastal sea complexes : This biotope complex includes both the benthic and pelagic ecosystems of the shallow water zone of the North Sea. The limit being a water depth where sand can still be transported by waves and currents and where the photic conditions are still sufficient for benthic macrophytes. This is to some extent dependent on water conditions and pollutants and can vary from about $12 \mathrm{~m}$ to a maximum of $20 \mathrm{~m}$ water depth. "Natural" means relatively low disturbance, for example no modification of the substrate by dredging or extraction of material, and relatively low water poilution. Types of biotopes present: 03.01, 03.02 all subtypes.

A3 Natural complexes of tidal flats: The diversity of tidal flats, vegetated or without vegetation, including different subtrate-types, as far as the water dynamics is natural and not reduced or heavily modified by coastal defence or shipping routes. It includes highly dynamic patterns of zonation and complete gully systems, as well as biogenic structures like blue mussel beds or congregations of tube-building polychaetes etc. The quality of the different flats has decreased greatly, mainly because of the impact of mussel and cockle fishery which has an impact on the biological quality, but also on the sediment dynamics and sediment composition. Locally, disturbance may lower the quality for foraging birds or seals. With proper policies the quality of most biota will be restored quickly, with the exemption of sea grass beds and stable mussel beds which may take decades to redevelop.

There are three subtypes that deserve special attention, as they are functional subunits to be taken into account for management plans and conservation:

A3.01 Tidal divide: Between two tidal inlets in general a clear tidal divide develops. These regions are characterized by tidal flats, small gullies and creeks, low current speeds, small median grain size and extensive mussel beds. The majority of these characters are dependent on physical processes and are therefore not threatened, as long as no dams to islands are constructed. Fisheries, and local disturbance, have decreased the quality of these areas, both biologically as well as from a sediment point of view. Restoration is simple by proper policies. Stable mussel beds and seagrass beds will take a long time to develop. Unstable, temporary mussel beds will probably restore the typical sediment characteristics of these areas.

Major types of biotopes present: 05.01.01-.03, 05.01.07, 09.01.

A3.02 Ebb delta: The ebb deltas in the seaward part of the tidal inlets are formed by physical forces, and are therefore not threatened from a quantitative point of view. The sandbanks between the gullies migrate in a clockwise direction and eventually join the next island. Some sandbanks may be so high that they are not covered at high tide. These banks serve as roosting places for birds and seals. Occasionally vegetation or small dunes may develop, but only temporarily as winter storms will flood these banks. Only disturbance has decreased the quality of this biotope. Restoration follows almost immediately after the implementation of regulations.

Major types of biotopes present: 05.01.01-.03, 05.03. 
A3.03 Complete gully systems: Complete gully systems stretching from the ebb- and flow gullies in the tidal inlet to secondary, tertiary and higher-level creeks in sand and mud flats or saltmarshes, and occurring in a natural state. Only locally are they impacted by physical processes. The quality of the biota in these systems is influenced by fisheries in the whole area. The impact is expected to increase with the ongoing increase in the power of the fishing vessels. Because of the dynamic character of the biotope and its biota, restoration will be quick.

Major types of biotopes present: 03, 05 especially 05.03.01, 05.03.02.

C1 Saltmarsh complexes (natural and seminatural): Along coastlines where sheltered conditions prevail, a typical zonation of saltmarsh complexes develop. In the vegetation belt, sedimentation occurs resulting in a sediment composition with a particle size finer than sand, often including relatively high amounts of organic matter and distinct layers of shell fragments. From the sea to the land the vegetation belts usually include different pioneer types of saltwort stands (Salicornia europaea agg.), Puccinellia-dominated grassland (Puccinellion), species-rich saltmarshes of Asteretea tripolii, for example Juncetum gerardii, up to more or less brackish marsh vegetation. Many other biotope types like gully systems, brackish reed vegetation etc. are intermingled.

Major types of biotopes present: 07, 05, 09, 10.01-10.03.

C1.01 Island saltmarsh complex: Island saltmarshes have almost all developed within sheltered regions; in the Netherlands behind artificial sand dikes. The sediment contains a larger fraction of sand than the mainland marshes. Island saltmarsh complexes are often found in close contact with transition zones to dune systems or sand flats covered with Salicornia dolichstachya ssp. (decumbens) with strong airborne sand drift. The protection levels are such that the quality is in most cases guaranteed. In some of the island marshes, a too high grazing pressure has lowered the quality. Also the use of four-wheel driven vehicles for maintenance has locally influenced the quality of the marsh. When island marshes are lost, restoration will often be difficult in a period with sea level rise and lack of suspended sediment.

Major types of biotopes present: 07.01.01, 07.02.01, 05.01.01, 05.02, 05.03.

C1.02 Mainland saltmarsh complex, natural: Mainland saltmarshes usually contain a larger fraction of silty and muddy material than the island saltmarsh complex. Natural zonation complexes from pioneer glasswort vegetation up to the transition zones towards freshwater marshes are very rare nowadays. In the Netherlands, especially those transition zones up to low-lying freshwater marshes have completely disappeared. Here, there may be some possibilities for restoration when new saltmarshes are developed in the summer polders. Because the land behind the sea dike lies lower than the saltmarsh, no natural flow of freshwater to the marsh will occur. Water will have to be pumped to the restored area. A completely natural development will therefore not be possible. Only with the help of large-scale projects in areas where the mainland is higher than the high tide level (southeast Groningen and Drente) are natural developments possible.

Major types of biotopes present: 07, 05, 09, 10.01, especially 07.01.01, 07.02.02.

C1.03 Slufter: A slufter is a dune valley in more or less open connection to the North Sea. They typically develop when the sea breaks through a dune ridge, or when an estuary along a sandy coast gradually fills up. It is not certain if slufters are naturally occurring long lasting biotopes. Most of the time, the elevation of the dune valley will be such that the tidal volume is not sufficient to keep a tidal inlet in existence. If the dune 
ridge closes again, the slufter will evolve into a primary dune valley. Two examples of slufters in The Netherlands are the "Zwin" on the Belgian/Dutch border and the "Slufter" on Texel. The Zwin has formed in the previous estuary of Brugge, and the Slufter developed after a break in the sand dike between the islands Texel and Eyerland. The flooded area consisted of previous tidal flats. Within slufters a great variety of biotopes will occur, ranging from intertidal flats and saltmarsh vegetation to areas covered with swamp- or fen-vegetation that varies with the salinity and the amount of lime in the soil. As slufters appear to be a stage in a succession, they are severely threatened if new slufters do not develop.

Major types of biotopes present: 10.01-10.03, 07, 05.

C3 Sand coast complexes (natural): Along coastlines with sedimentation of sands in sufficiently large quantities, a zonation complex with sand beaches, drift lines, embryonic dunes and the whole system of developing white, grey and brown dunes arises. Dune formation and succession series mainly depend on sedimentation rates of sand, average wind conditions and from the Ca-content of the deposited material. Natural undisturbed complexes are rare, as in most cases either coastal defence limits the dynamics of sand transportation, or part of the biotope types have already been destroyed by building activities, tourism etc.

Major types of biotopes present: 05, 09, 10, 11.03.

Three Subtypes, forming functional units, are of special importance:

C3.01 Dune-tidal flats transition zone: Many island transitions between dunes and tidal flats can be found, but both quantitatively and qualitatively they cannot be compared with the natural situation. Especially the transition from old dunes to tidal flat has become rare. The biggest threat is coastal defence. In inhabited areas restoration will be difficult, but with proper management prospects for restoration are promising.

Major types of biotopes present: 05, 09, 10.

C3.02 Pleistocene tidal flats/saltmarsh transition zone: Only in a few places in The Netherlands and in Germany does a natural transition between the pleistocene (geest) and tidal flats or saltmarshes still exist (NL: Texel, Wieringen, Zuiderzee islands and coast, and Bergen op Zoom; D: Nordfriesische Inseln, esp. Sylt, Amrum). In NL these places are now separated from sea by polders, stretches of freshwater or dikes. The only place where restoration is feasible is along parts of the northern shore of Wieringen. Major types of biotopes present: 09, 05, 07.

C3.03 "Washover": Washovers occur when the sea breaks through a single dune ridge which separates the North Sea beach from the beach plain along the Wadden Sea. Permanent gullies are not formed, but eolian erosion will create a diversity in biotopes. Sand will become available for the development of new biotopes. Conservative coastal defence and dune management are the biggest threat for washovers from a quantitative point of view. Major types of biotopes present: 09, 10.

\section{PART II: Biotope types}

The definitions of biotope types are mainly based on the Red Data book of Biotopes for Germany (Riecken et al., 1994) and have been adapted, including the concepts of The Netherlands. The list is arranged in groups of biotope types in a hierarchical way. 
03. Shallow coastal water zone: The shallow coastal water zone includes the sublittoral, i.e. the sea bottom from the MLT-line to the deepest distribution of benthic macrophytes (ca 15-20m below MLT, for practical convenience the $20 \mathrm{~m}$ depth line can be taken) and the water body on top. This complex is roughly divided into the pelagic zone and the benthic zone.

03.01 Pelagic zone of the shallow coastal waters: Water body of the shallow coastal water zone. The coastal sea is considered to be the region between the islands and ca the $20 \mathrm{~m}$ depth line. There are several types of impact. The majority of impacts does not seriously threaten the quality as a whole. Fisheries and pollution have an influence on the area as a whole. Part of the direct fishery impact can be stopped by closing areas. Changes in fish stocks or species composition are to a large extent caused by fishery activities in the rest of the North Sea. Improving the quality in this aspect may be possible by closing large areas of the North Sea for fisheries, including the adjoining parts of the nurseries inside the Wadden Sea.

Factors of threat: eutrophication and pollution (waste-water inlets, heavy-metal input, oil pollution, dumping) intensive fishery, shipping.

03.02 Benthic zone of the shallow coastal waters of the North Sea: Sublittoral sea bottom of the shallow coastal water zone of the North Sea between MLT and ca $15 \mathrm{~m}$ depth with benthic plant and animal communities. In this area macrophytes and macroalgae can occur due to favourable or sufficient light conditions; further division according to substrate types and vegetation cover.

Vegetation communities: Ruppion maritimae Br.-Bl. 31 em Den Hart. et Seg. 64, Zosteretum marinae Harms. 36 .

Factors of threat: eutrophication and pollution (waste-water inlets, heavy-metal input, oil pollution, dumping), groundnet fishery, oil exploitation.

03.02.01 Benthic zone of the shallow coastal waters with muddy bottom and few macrophytes: Sea bottom with poor vegetation of the shallow coastal waters of the North Sea with a substrate of clay and mud (prevailing particle size $<0.06 \mathrm{~mm}$ ).

Factors of threat: eutrophication and pollution (waste-water inlets, heavy-metal input, oil pollution, dumping), groundnet fishery, dyking, oil exploitation.

03.02.02 Benthic zone of the shallow coastal waters with fine to medium sand bottom, few macrophytes: Sea bottom, poor in vegetation, of the shallow coastal waters of the North Sea with a substrate of fine to medium sand (prevailing particle size between 0.06 and $0.6 \mathrm{~mm}$ ).

Factors of threat: eutrophication and pollution (waste-water inlets, heavy-metal input, oil pollution, dumping, mud accumulation), groundnet fishery, dyking, extraction of sand, oil exploitation.

03.02.02.a Sand bank (permanently submerged)

03.02.03 Benthic zone of the shallow coastal waters, coarse sand, gravel or shells bottoms, few macrophytes: Sea bottom of the shallow coastal waters, without vegetation or with few macrophytes only, with a substrate of coarse sand - gravel or mussel shells (prevailing particle size between $0.6->2 \mathrm{~mm}$ ).

Factors of threat: eutrophication and pollution (waste-water inlets, heavy-metal input, oil pollution, dumping, mud accumulation), groundnet fishery, dyking, extraction of sand and gravel, oil exploitation. 
03.02.04 Benthic zone of the shallow coastal waters with stony and hard bottom, few macrophytes: Sea bottom, with hard substrates, of the shallow coastal water zone without vegetation or with few macrophytes only, mostly with rock, pebble or coarse stone. Hard substrates can be considered rare in the Dutch Wadden Sea. Natural hard substrates are fossil shell banks, clay and peat banks or gravel and boulders which come to the surface if gullies cut through old sediments. These biotopes often contain open spaces which are used as shelter by a variety of organisms. They also act as a substrate for sedentary organisms, and some fish species require hard substrate for depositing and attaching their eggs. Several organisms which drill holes in peat, clay or wood are fully dependent on this biotope type.

Factors of threat: eutrophication and pollution (waste-water inlets, heavy-metal input, oil pollution, dumping, mud accumulation), groundnet fishery, dyking, oil exploitation.

03.02.05 Benthic zone of the shallow coastal waters with muddy and sandy bottom, rich in macrophytes: Upper parts of the sublittoral of the North Sea with muddy or sandy bottom, covered with Zostera marina or Ruppia maritima agg. - vegetation. The main vegetation consists of subtidal seagrass beds (dense stands of Zostera marina). The subtidal seagrass beds in the Dutch Wadden Sea area have been extinct since the early $1930 \mathrm{~s}$ because of a disease. In the Dutch Wadden Sea the area might have been up to 5000 ha, and the only other big stand in the Wadden Sea occurred in Königshafen in Sylt. In Germany subtidal seagrass beds still exist and have partly recovered from their decline. The seagrass stands form a biotope for a number of rare species especially for breeding of fishes. Reduced currents, muddy sediments, and cover favours egg laying and larval development.

Vegetation communities: Zosteretum marinae Harms. 36, Ruppion maritimae Br.-Bl. 31 em. Den Hart. et Seg. 64.

Factors of threat: eutrophication and pollution (waste-water inlets, heavy-metal input, oil pollution, dumping, mud accumulation), groundnet fishery, dyking, oil exploitation.

03.02.06 Benthic zone of the shallow coastal waters with hard bottom and rich in macrophytes: Upper parts of the sublittoral of the North Sea with hard bottom, mostly covered with large brown algae (Laminaria saccharina, L. digitata, L. hyperborea, partly Fucus serratus). In deeper areas with increasing amounts of small red algae; in Germany naturally only outside the Wadden Sea region on the rock-base of Helgoland (blue mussel beds covered with algae s. 03.02.07). Hard substrates can be considered rare in the Dutch Wadden Sea as well. Natural hard substrates are fossil shell banks, clay and peat banks or gravel and boulders which come to the surface if gullies cut through old sediments. These biotopes often contain open spaces which are used as shelter by a variety of organisms. They also act as a substrate for sedentary organisms, and some fish species require hard substrate for depositing and attaching their eggs. Several organisms which drill holes in peat, clay or wood are fully dependent on this biotope type.

Factors of threat: eutrophication and pollution (waste-water inlets, heavy-metal input, oil pollution, dumping, mud accumulation), groundnet fishery, extraction of sand, oil exploitation.

03.02.07 Blue-mussel bed of the sublittoral: Colony of blue mussels (Mytilus edulis) in the subtidal region. Blue mussel beds also occur in the intertidal region (see 05.01.07). 
Mytilus edulis is a species that doesn't need to live directly on the sea floor but builds thick, multi-layered mussel beds with its byssus. The mussel bed creates a hard substrate in the sandy or muddy surroundings, partly with a more or less dense cover of brown algae (mostly Fucus vesiculosus and $F$. serratus). Stocks are partly initiated by the mussel culture; threatened mussel beds are several years old and naturally grown. There are indications that the beds in the subtidal zone are not very stable and do not form old structures.

Factors of threat: pollution (heavy-metal input, oil pollution, dumping, mud accumulation), particularly old, natural stocks are threatened by intensive fishery.

03.02.08 Sublittoral oyster reef: Oyster reefs have been extinct since last century. Like mussel beds, oyster reefs are the basis for complex biological communities. A study on an oyster reef in the Wadden Sea resulted in the introduction of the term 'biocenosis' in ecology, well over a hundred years ago. The flat oyster Ostrea edulis has disappeared from the Wadden Sea. Attempts at reintroduction have not been successful. In some places the introduced Japanese oyster Crasostrea virga is surviving and reproducing. Reefbuilding has been observed in the Eastern Scheldt, but not in the Wadden Sea. It is not clear whether the present conditions in the Wadden Sea are suitable for the development of reefs of the flat oyster.

03.02.09 Sublittoral Sabellaria reef: The reefbuilding polychaete Sabellaria sp. is still occurring in the Wadden Sea. Extensive reefs can be considered extinct for the Dutch Wadden Sea, although it is not clear whether they ever occurred in the Dutch part of the Wadden Sea. In Germany the reefs have largely disappeared because of fishing activities with sediment-disturbing trawls and dredges. Regeneration may be possible in areas which are closed for fishery with bottom gear. It is not known whether these reefs will redevelop if fishery is stopped.

Factors of threat: pollution (waste-water inlet, heavy-metal input, oil pollution, dumping), intensive fishery, groundnet fishery.

03.02.10 "Seamoss" stand: Colony of diverse species of hydropolyps (i.e. Sertularia spp., Hydralmannia spp.) on hard bottom, also on mussel beds or shell substrates.

Factors of threat: pollution (waste-water inlet, heavy-metal input, oil pollution, dumping), intensive fishery, groundnet fishery.

03.09 Artificial benthic hard substrates: A special type of biotope are artificial rocky shores, (dikes and breakwaters) and wrecks of wooden or metal vessels often with very rich growth of macrophytes. They may be of great value as they provide secondary biotopes substituting rare primary ones and they increase the diversity. They may have a dense cover of macrophytes.

05 Tidal flats (eulittoral): Flats of the North Sea, periodically falling dry at low tide, also occurring in estuaries, situated between MLT and MHT. Typical are great amplitudes of temperature, light and salinity, high eutrophication and input of organic substances from rivers and the open sea. Multiple forms of organisms, from microscopic diatomes over mussels, worms to green algae and seagrass, settle in this area within or on the substrate. They play an essential role in the trophic pyramid and support a high variety of birds and fish. This type is subdivided into substrate types, vegetation cover and salinity of the water.

05.01 Tidal flats, free of vegetation: Tidal flats of the North Sea without macrophytes 
(normally covered by thin layers of blue algae and diatoms). This type can be subdivided according to substrate types and the salinity of the water.

Factors of threat: eutrophication and pollution (waste-water inlets, heavy-metal input, oil pollution), groundnet fishery, dyking, poldering, oil/gas exploitation, military target areas, shipping, intensive recreational use.

05.01.01 Mud flats, free of vegetation: Mud flats free of vegetation, of higher plants or macroalgae, covers of microalgae are frequent; with sediments of finest material, at least half of the sediment consisting of silt and clay (grain size $<0.06 \mathrm{~mm}$ ).

Factors of threat: eutrophication and pollution (waste-water inlets, heavy-metal input, oil pollution), groundnet fishery, dyking, poldering, oil/gas exploitation, military target areas, shipping, intensive recreational use.

05.01.02 Mixed flats, free of vegetation: Mixed mud and sand flats with grain fractions of sand between $50-85 \%$ fine sand; mostly free of macrophytic vegetation; covers of microalgae may be present.

Factors of threat: eutrophication and pollution (waste-water inlets, heavy-metal input, oil pollution), groundnet fishery, dyking, poldering, oil/gas exploitation, military target areas, shipping, intensive recreational use.

05.01.03 Sand flat, free of vegetation: Flats with a sediment consisting of more than $85 \%$ of fine sand $(0.06-0.2 \mathrm{~mm})$, mostly free of macrophytic vegetation. Especially in sand flats, tube-building polychaetes like Lanice conchilega may develop dense colonies, giving rise to specific structures (biotope-elements) with a quick sedimentation in the order of more than $0.5 \mathrm{~m}$ per year, compared to surrounding parts of the flat.

Factors of threat: eutrophication and pollution (waste-water inlets, heavy-metal input, oil pollution), groundnet fishery, dyking, poldering, oil/gas exploitation, military target areas, shipping, intensive recreational use, extraction of sand.

05.01.03.01 Sand flat, free of vegetation: Pure tidal sand flats without specialized algal communities.

05.01.03.02 „Farbstreifen“ sand flat ("colour-striped sand flat“): Special subtype of tidal sand flats, typically with coloured stripes of photosynthetically active layers of microbes with a thickness of $2-20 \mathrm{~mm}$; consisting of a surface sand layer (by accumulated sand) that glimmers bluegreen due to cyanobacteria, purple to pink due to sulfurpurple bacteria and black caused by sulfur- and iron-reducing bacteria.

Factors of threat: eutrophication and pollution (waste-water inlets, heavy-metal input, oil pollution), groundnet fishery, dyking, poldering, oil/gas exploitation, military target areas, shipping, intensive recreational use.

05.01.03.03 Sandbank (eulittoral zone): Sandbanks isolated from the coast, beneath the MHT, falling dry at low tide. Due to their state of relatively low disturbance they are of importance as resting place for seals.

Factors of threat: eutrophication and pollution (waste-water inlets, heavy-metal input, oil pollution), military target areas, shipping, intensive recreational use by boats.

05.01.05 Brackish tidal flats of estuaries: Tidal flats of estuaries periodically falling dry at low tide, with typical lowered and varying salinity due both to influence of rainand river-freshwater. With the loss of the estuaries, also the floodplain along the estuary and the river have become extinct in the Dutch Wadden Sea. Restoration may be possible along the Westerwoldse $\mathrm{Aa}$, but only after large-scale engineering and major destruction. In Germany there are good possibilities along the Weser, Elbe and Eider. 
Vegetation communities: Thero-Salicornietea Pign. 53 em. Tx. 55, Ruppion maritimae Br.-Bl. 31 em. Den Hart. et Seg. 64 u.a.

Factors of threat: Dyking of river marshes, coastal protection, constructions of embankments, eutrophication and pollution (fertilizer- and pesticide input by intensive agriculture, waste-water inlets, heavy-metal input, oil pollution), shipping.

05.01.06 Freshwater tidal flats of estuaries: Flats of estuaries, covered with shallow freshwater at high tide and periodically falling dry at low tide; no influence of brackish or saltwater except during extreme storms. The freshwater tidal regions are extinct in the Dutch part of the Wadden Sea. In Germany possibilities for restoration exist along the rivers Elbe, Weser, Hunte and Eider.

Factors of threat: Dyking of river marshes, coastal protection, constructions of embankments, eutrophication and pollution (fertilizer- and pesticide input by intensive agriculture, waste-water inlets, heavy-metal input, oil pollution), shipping.

05.01.07 Eulittoral (old) blue mussel beds: Colony of blue mussels (Mytilus edulis) in the intertidal region. Blue mussel beds also occur in the subtidal region (see 030207). $M Y$ tilus edulis is a species that does not need to live directly on the sea floor but builds thick, multi-layered mussel beds with its byssus. The mussel bed creates a hard substrate in the sandy or muddy surroundings, partly with a more or less dense cover of brown algae (mostly Fucus vesiculosus and F. serratus). Mussel beds, several years of age and naturally grown, are threatened. Intertidal beds have been known to survive for decades. An intertidal bed contains mussels of different age classes. Species richness and diversity are positively correlated with age and structural complexity of the bed. In a mature bed in the Wadden Sea 96 associated species have been recorded. In the Dutch Wadden Sea it was shown that $25 \%$ of the birds occurred on the mussel beds while these covered only $5 \%$ of the area. Intertidal mussel beds have been under severe stress in the Wadden Sea. In the 1950s fishermen tried to destroy them, because the beds were thought to be a vector in the spread of a parasite which was considered to be a threat for the mussel culture. Mature beds can now be considered almost extinct. It has been shown that formation of new beds is a rare event, because settlement in general only takes place on existing beds or remains of old beds.

Restoration of intertidal mature mussel beds may be possible if a complete ban is imposed on destruction of intertidal beds. The majority of the developing beds will not be stable, but a small part of them may develop into mature beds. With the present fishery regulations and management plans, the mussel bed should be considered an endangered biotope.

Factors of threat: pollution (heavy-metal input, oil pollution); particularly old, natural stocks are threatened by intensive fishery.

05.02 Tidal flats with vegetation: Usually mud flats, with a more or less dense cover of macrophytes.

Vegetation communities: Thero-Salicomietea Pign. 53 em. Tx. 55, Spartinetea Tx. 61, z. T. Zosteretea marinae Pign. 53.

Factors of threat: eutrophication and pollution (waste-water inlets, heavy-metal input, oil pollution), dyking, poldering.

05.02.01 Intertidal Seagrass beds: Slender sea grass meadows (Zostera noltii and $Z$. marina ssp. angustifolia) in the lowest tidal zone close to MLT or in shallow depressions of the medium or low tidal flat zones; more or less periodically falling dry for a short time; 
Intertidal seagrass beds have decreased in abundance over the last decades. In a few parts of the Wadden Sea the decrease seems to have halted during the last ten years. The beds are very susceptible for sediment-disturbing activities. Compared with the German Wadden Sea, only a very small percentage of the Dutch part is covered by seagrass. The intertidal seagrass used to be an important food source for Brent geese. As it is not clear what caused the decline of the intertidal seagrass, it is difficult to predict whether the fields will regenerate.

Vegetation communities: e.g. Zosteretum noltii Harms. 36, Zosteretum marinae partly.

Factors of threat: pollution (waste-water inlets, heavy-metal input, oil pollution), dyking, intensive recreational use, bottom disturbing fishery (cockle fishery).

05.02.02 Tidal flats with saltwort stands (Salicornia): Situated above the seagrass zone, often monospecific, by root competition very gappy stands of different species of Salicornia (S. europaea agg.), growing either upright or prostrate.

Vegetation communities: Thero-Salicornietea Pign. 53 em. Tx. 55: z.B. Salicornietum dolichostachyae (strictae) Knauer 52, Salicornietum ramosissimae Christians. 55 em. Tx. 74 .

Factors of threat: pollution (waste-water inlets, heavy-metal input, oil pollution), dyking.

05.02.03 Tidal flats with Spartina anglica stands: Thickets of Spartina anglica in

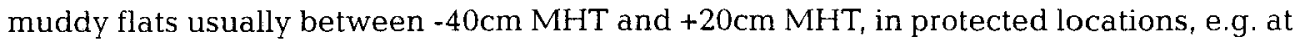
sea embankments. Partly located in the higher Salicornia zone and in the Puccinelia zone and displacing Salicornia and Puccinellia. Often, but in most cases without success, planted for land reclamation purposes.

Vegetation communities: Spartinetea Tx. 61: Spartinetum anglicae Corill. 53.

05.02.04 Bogs in tidal erosion (e.g. Sehestedter Moor): The only example on the German North Sea coast is the "Sehestedter Moor", the rest of a Sphagnum bog, located in the "Jadebusen" (Niedersachsen) seaward of the dike. Its step by step erosion is based on the dynamics of tidal currents.

Factor of threat: natural erosion and possibly eutrophication.

05.03 Tidal gullies and channels: Channels and gullies formed by tidal currents with steep slopes and undercut banks located in tidal flats of the North Sea and extending into the shallow water zone; differentiated by width and length; periodically or always flooded and under constant changes.

Vegetation communities: at channel slopes: Halimionetum portulacoides Kuhnh.-Lord. 27. Suaeda macrocarpa Communities e.g. (Asteretea tripolii Westh. et Beeft. in Westh. et al. 62, Thero-Salicornietea Pign. 53 em Tx. 55).

Factors of threat: pollution (waste-water inlets, heavy-metal input, oilpollution), groundnet fishery, eutrophication, dyking.

05.03.01 Tidal gullies and channels, permanently submerged

05.03.02 Channels and gullies, dry at low tide

07 Saltmarshes and -meadows: Includes natural and anthropogenic meadows, pastures and marsh areas that are no longer grazed or mowed on episodically flooded muddy and sandy bottoms on the North Sea coast. Located above MHT, different zones depend on frequency and lasting of flooding and on the salinity of the soil water. Mostly composed of perennial grass species and herbs in compact stands. 
07.01 Lower saltmarshes: Lower zone of the saltmarsh, beginning at the zone of glassworts (Salicornia), ca $-20 \mathrm{~cm}$ to $+25 \mathrm{~cm}$ MHT, mainly with Puccinella - grassland; \pm permanently under saltwater conditions, helping land reclamation carrying more or less dense vegetation, in most cases dominated by Puccinella maritima.

07.01.01 Lower saltmarshes, natural or seminatural: Lower saltmarsh of the North Sea, rich in structure, not or only very extensively used.

Vegetation communities: Puccinellion maritimae Christians. 27 em. Tx. 37, and: SaginoCochlearietum danicae Tx. et Gilln. 57.

Factors of threat: eutrophication and pollution (waste-water inlets, heavy-metal input, oilpollution), dyking, poldering, recreational use, sheep grazing.

07.01.02 Lower saltmarshes, anthropozoogenic: Lower saltmarsh of the North Sea, due to grazing or mowing poorer in species and structure than natural marshes; mostly very low growth with dominating Puccinellia maritima. In the whole Wadden Sea mainland marshes were increased in area by stimulating sedimentation. These marshes served a function in coastal protection and as grazing area for livestock. The man-made marshes contain the same vegetation types as the natural marshes.

Vegetation communities: Puccinellion maritimae Christians. 27 em. Tx. 37, and: SaginoCochlearietum danicae Tx. et Gilln. 57.

Factors of threat: pollution (waste-water inlets, heavy-metal input, oilpollution), dyking, poldering, recreational use, intensification of agriculture.

07.02 Upper saltmarshes of the North Sea: Following the Puccinella-marshland further inland, about $20-30 \mathrm{~cm}$ above MHT, a marshland with less flooded grassland vegetation exists; better air conditions in the soil and initial freshwater influence in the ground water table; naturally very rich in both structures and species.

07.02.01 Upper saltmarshes, natural or seminatural: Upper saltmarsh of the North Sea (e.g. in the "Halligen", German part of the Wadden Sea), rich in structure, no or only very extensive use.

Vegetation communities: Armerion maritimae Br.-Bl. et de L. 36, v.a. Juncetum gerardii (Warming 06) Du Rietz 23, and: Sagino-Cochlearietum danicae Tx. et Gilln. 57.

Factors of threat: eutrophication and pollution (waste-water inlets, heavy-metal input, oilpollution), dyking, poldering, intensive recreational use, intensification of agriculture.

07.02.02 Upper saltmarshes, anthropozoogenic: Upper saltmarsh of the North Sea, due to grazing or mowing poorer in species and structure than natural marshes. In the whole Wadden Sea mainland marshes were increased in area by stimulating sedimentation. These marshes served a function in coastal protection and as grazing area for livestock. When the marsh surface had gained sufficient height, the area was embanked by dikes. In the past centuries, embankments surpassed new accretion so much that the saltmarsh area today is only a small part of that expected in a reference situation. The manmade marshes contain the same vegetation types as the natural marshes. The main difference is the unnatural structure of the drainage channels and the high density of these channels.

The quality of the marsh depends greatly on the type of active management. Studies are under way to develop management techniques which make an optimal use of the natural processes. 
Vegetation communities: Armerion maritimae Br.-Bl. et de L. 36, v.a. Juncetum gerardii (Warming 06) Du Rietz 23.

Factors of threat: eutrophication and pollution (waste-water inlets, heavy-metal input, oilpollution), dyking, poldering, recreational use, intensification of agriculture, sheep-grazing.

07.03 Green beach (Strandwiese): Beach, richly structured by gully-systems and embryonic dune systems, which cannot be assigned to the lower or upper saltmarsh because of its small structured biotope mosaic. These biotopes develop behind dune ridges and beach barrier systems, but are regularly flooded by seawater. The vegetation is similar to the saltmarshes, but also juvenile stages of dunes occur. Relics of these dynamic biotopes occur in slufters and on the beach plains. The biggest threat is coastal protection and dune management both for the area and for the quality of the biotope. An additional threat for the quality is disturbance. As is the case with most dynamic biotopes, restoration is relatively easy.

Vegetation communities: e.g. Puccinellion maritimae Christinas. 27 em. Tx. 37, Armerion maritimae Br.-Bl. et Del. 36, Cakiletea maritimae Tx. et Prsg. 50.

Factors of threat: eutrophication and pollution (waste-water inlets, heavy-metal input, oilpollution), dyking, poldering, intensive recreational use, intensification of agriculture.

07.04 Brackish and saltwater reed marsh: Reeds under salt- or brackish-water influence on the shores of the North Sea islands, on the mainland, along coastal lakes, in estuaries, on slopes of gullies or in wet dune valleys. The most common plants are Phragmites australis, Bolboschoenus maritimus ssp. compactus, Schoenoplectus tabernaemontani .

Vegetation communities: Scirpion maritimi Dahl et Had. 41: Scirpetum maritimae Tx. 37 , partly Phragmition communis W. Koch 26: Phragmitetum vulgaris SogulliesFactors of threat: eutrophication and pollution (waste-water inlets, heavy-metal input, oilpollution), dyking, intensive recreational use, agriculture.

07.05 Brackish tall herb stands: Tall herb stands at coastal lakes when sedimentation fills them up, in brackish fallows, in wet dune valleys or on shores of estuaries.

Vegetation communities: partly Senecion fluviatilis Tx. 50, e.g. Convolvulo-Angelicetum archangelicae litoralis Pass. 59.

Factors of threat: eutrophication and pollution (waste-water inlets, heavy-metal input, oilpollution), dyking, intensive recreational use, agriculture.

07.06 Brackish saltmarsh of estuaries: Commonly grazed, brackish (poldered) meadows in tidal zones of estuaries or in new polders that are still influenced by salt water. The latter underlie an ongoing decrease in salinity and evolve in most cases to intensively used grassland, or become arable land.

Vegetation communities: Armerion maritimae Br.-Bl. et De L. 36, Potentillion anserinae Tx. 47 (Agropyro-Rumicion).

Factors of threat: eutrophication and pollution (waste-water inlets, heavy-metal input, oilpollution), dyking, intensification of agriculture.

09 Sands and beaches: Sandy and gravel beaches in the coastal zones of North Sea islands and the mainland; located above the periodically flooded zone. Commonly free of vegetation, often with drift lines or accumulations of dead algae along the shore, partly covered with vegetation. 
09.01 Sandbanks and sands of the backshore: Sands above MHT that are only episodically flooded and isolated from the coast; dune evolution possible when sand supply is high.

Factors of threat: intensive recreational use, shipping, pollution (e.g. oil, other harmful organic matter, garbage, heavy-metal input).

09.02 Sandy beach: Sand flats at the coast, influenced by salt and airborne sand drift. Sandy beaches are in most cases free of vegetation, but often with drift lines of organic matter (e.g. algae and sea grass) along the shore, the upper ones are often covered with characteristic vegetation (Atriplicon littoralis); included are also sand flats covered with Salicornia dolichstachya ssp. (decumbens) with strong airborne sand drift; on natural beaches dunes occur landward.

The quality of the remaining natural and undisturbed beaches has shown a considerable deterioration, mainly because of disturbance. Whelping areas for seals, and breeding areas for spezialized birds have become rare or extinct. With proper policies and management, restoration will be simple and promising. Migrating sandbars as a very dynamic biotope can cover part of the sand beach. Few organisms will use these as a permanent biotope. Only locally will management activities (dredging, coastal defence etc) influence the relevant physical processes. The biotope is considered qualitatively and quantitatively healthy and will restore quickly if affected.

Vegetation communities: Cakiletea maritimae Tx. et Prsg. 50, Honkenyo-Elymion Tx. 66 em. Géhu et Tx. in Géhu 75, Salicornietum x decumbentis Schwabe et Tx. 77.

Factors of threat: intensive recreational use, pollution (e.g. oil, other harmful organic matter, garbage, heavy-metal input), removing of drift line material (cleaning of the beach).

09.05 Beach ridge: Ridges in different mixtures of sand, pebbles, shingles, algae and water plants, sedimented on the beach by dynamic processes, such as currents, breakers and ice pressing. Depending on its degree of succession, free of vegetation or covered with drift line communities. At erosive coasts when fossil peat layers are eroded, beach ridges of peat or clay may occur.

Factors of threat: intensive recreational use, coastal defence measures.

09.06 Coastal lake: Lakes with brackish- or saltwater, separated from the sea at low water levels by beach ridges or large spits, in most cases poor in vegetation. Location and habitus can often be changed by flooding. With growing beach ridges and spits, such lakes can become totally separated from seawater inflow and will develop into brackishand later into freshwater lakes of the hinterland.

Brackish inland waters are in most cases not natural biotopes in the Wadden Sea region, but they can be important from a nature conservation point of view. In Germany some large saline or brackish still waters occur. In The Netherlands it would be possible to develop the Lauwersmeer into such an area. Before the dikes were of the standard as we know them today, seepage of saline water caused small brackish pools or terrestrial biotopes to develop behind the dikes. These biotopes are rare. They may contain the last remnants of an earlier abundant brackish-water fauna. Restoration is relatively easy by letting in salt water, but this may interfere with agricultural practice.

Vegetation communities: e.g. Ruppion maritimae Br.-Bl. em Den Hart. et Seg. 64.

Factors of threat: intensive recreational use, pollution (e.g. waste-water inlet, oil, heavymetal input), dumping of e.g. garbage. 
10 Coastal dunes: Sandy hills of different height, accumulated by wind along sandy beaches. Depending on its degree of succession, poor in vegetation, covered with fragmentary grass stands, heather or shrubberies.

10.01 Primary dunes: Beginning of dune succession: embryonic or primary dunes. These are low, often strongly windswept and saltwater-influenced sand accumulations on the upper beach; in most cases, only fragmentary cover of tufts of Agropyrum junceum is present. When series of beach dunes connect with each other, dune ridges are formed. A young dune ridge is present for example at the Hors on Texel, but to a large extent it should be considered man-made. Dune ridges are not threatened, but due to their scale, regeneration will be difficult.

Vegetation communities: Agropyrion junceiformis Géhu 75.

Factors of threat: trampling through intensive recreational use.

10.02 White dunes: Secondary dune: already higher dune with preliminary development of freshwater lentils, groundwater in most cases still rich in lime (shell fragments); undergoes permanent sand accumulation, mostly fragmentary cover with beach grass. (Ammophila arenaria, Ammocalamagrostis x baltica); The term secondary refers to the stage of dune development, while the dune formation itself may be primary or secondary due to erosion on coastlines with break-throughs in older dune ridges or due to human degradation. Vegetation communities: Ammophilion arenariae (Br.-Bl. 33) Tx. 55, Honkenyo-Elymion Tx. 66 em. Géhu et Tx. in Géhu 75 .

Factors of threat: protective measures against erosion, coastal defence measures, recreational use (camping, trampling).

10.03 Grey dune grassland: Last stage of dune development before dune scrub invades with more or less dense vegetation cover; in most cases higher dune, with an already decalcified, acidic upper soil layer with low moderate humus accumulation; only little sand supply, covered with nutrient poor grassland on sand; in some cases dense moss or lichen carpets can develop.

Vegetation communities: Koelerion arenariae Tx. 37 corr. Gutermann et Mucina 93 (Koelerion albescentis), Corynephorion canescentis Klika 31, Thero-Airion Tx. et Oberd. 57, u.a.

Factors of threat: protective measures against erosion, coastal defence measures, recreational use (camping, trampling).

10.04.01 Dunes and coastal heath with Empetrum nigrum: Primary, dwarf heather on brown dunes with cranberries (Empetrum nigrum) at locations that undergo only little accumulation of wind-blown sand. The soil is acidic with distinct accumulation of humus, a beginning podsolization is visible.

Vegetation communities: Empetrion nigri Böch. 43.

Factors of threat: protective measures against erosion, coastal defence measures, recreational use (camping, trampling), game bite off.

10.04.02 Dune heath with Calluna vulgaris: Brown dune, in most cases preserved by extensive grazing with dominating common heather (Calluna vulgaris). The soil is acidic with distinct accumulation of humus, a beginning podsolization is visible.

Vegetation communities: Genistion pilosae Duv. 42 em. Schub. 60: v.a. Genisto anglicaeCallunetum Schwick. 33 em. Tx. 75.

Factors of threat: protective measures against erosion, coastal defence measures, recreational use (camping, trampling), game bite off esp. by rabbits. 
10.05 Wet dune valleys (incl. coastal fens): Valley within the dune belt of the coast, formed by deflation or coastal erosion. Due to groundwater contact covered with swampor fenvegetation that varies with the salinity and the amount of lime in the soil. Because precipitation is higher than evaporation, the vegetation loses the salt-tolerant taxa. Dune valleys occur on all islands, and in The Netherlands the majority is managed as nature reserve. When dune valleys are not completely separated from the sea or when the sea breaks through the ridge, a slufter is formed.

Within wet dune valleys dune lakes may occur:

The first type of dune lake develops when eolian erosion in dune valleys proceeds until the soil water level is reached. This type of dune lake develops on bare sand and is poor in nutrients. Many of these lakes are temporary, and contain water only in winter. The second type of dune lake develops when a dune system enlarges and the groundwater level rises. These dune lakes develop in vegetated valleys and are relatively rich in nutrients. Permanent dune lakes are rare and their biggest threat is exploitation of freshwater for inhabitants and tourists.

Vegetation communities: Asteretea tripolii Westh. et Beetf. in Westh. et al. 62, Phragmitetalia Koch 26, Isoeto-Nanojuncetea Br.-Bl. et Tx. ex Westh. et al. 46, Ericetum tetralicis Jonas 32, Bolboschoenetalia maritimi Hejn`y in Holub et al. 67.

Factors of threat: trampling through recreational use, exploitation of freshwater or groundwater, eutrophication.

(23.01) Dune brooks: Because the amount of rainfall exceeds the amount of evaporation, and the ground water level is higher than the surrounding area or sea, water seeps out of dunes. When dune systems are of sufficient size, brooks or creeks may be formed. These can either flow towards land or towards the sea. If the latter is the case, an extremely rare subtype develops. In its optimal form it resembles a small estuary containing the whole range from mud flat, saltmarsh to freshwater marsh. The only relatively well preserved example in The Netherlands is the Moksloot on Texel, although saltwater intrusion is prevented there. Further restoration seems possible.

10.06 Dune scrub (natural): With ongoing succession on dunes (with e.g. sand consolidation, enrichment of humus, decalcified soil), shrubs and thickets of Salix repens, Hippophae rhamnoides, or Rosa pimpinellifolia develop; Thickets of non autochthonous species, e.g. Rosa rugosa, are not included.

Vegetation communities: e.g. Salicion arenariae Tx. 52, z.T. Pruno-Rubion fruticosi Tx. 52 corr. Doing 62.

Factors of threat: plantation of non autochthonous species, trampling through recreational use, game bite off.

10.07 Natural shifting dune: Dune moving due to strong airborne sand drift in the main wind direction; almost free of vegetation. This type of dune can be primary when no vegetation has developed. It can also be of a secondary nature after vegetation has disappeared. In Germany it usually develops after degradation of white-, grey- and brown dunes. Because of intensive management and stimulation of vegetation development, this type has become rare; restoration is relatively simple.

Factors of threat: protective measures against erosion (conservative management)

11.03 Pleistocene cliffs: Smaller pleistocene cliffs (Geest) along the coast of the North Frisian islands.

Factors of threat: direct destruction by buildings and constructions. 


\section{LEGEND TO THE TABLES}

The three-pronged criteria system used in the red list of biotopes and biotope complexes comprises two criteria of threat and an assessment of the regeneration ability. The criteria of threat are given for each subregion separately, while the assessment of the regeneration ability, together with an overall evaluation of threat, is given for the region of the Wadden Sea as a whole. The 'Red List of Biotopes and Biotope Complexes of the Wadden Sea Area' is an alphabetical list grouped by the overall status of biotope types and biotope complexes. The 'List of threatened Biotopes and Biotope Complexes of the Wadden Sea Area' gives a complete hierarchical red list of the biotope complexes and biotopes of the Wadden Sea area with regional evaluations, main threats and further information.

DE: Threat by direct destruction (Loss of area)

QU: Threat by qualitative changes (loss of quality, i.e. adverse changes of abiotic conditions, of the typical structural appearance, and of the typical set of plant and animal species present).

0 completely destroyed

1 threatened by complete destruction

2 heavily endangered

3 endangered (vulnerable)

$\mathbf{P}$ potentially endangered (susceptible); this category is only used for criterion DE (threat by direct destruction)

- presumably not endangered at present

- not present

OE: Overall evaluation of threat: Both criteria (direct destruction and qualitative change) are combined to give an overall classification of threat. This has at least the same level of the highest rank given in one of the criteria I and II.

\section{RE: Assessment of regeneration ability}

$\mathbf{N}$ regeneration impossible

$\mathbf{K}$ regeneration hardly possible ( $>150$ years necessary)

$\mathrm{S}$ regeneration difficult (15-150 years)

B regeneration conditionally possible (less then 15 years)

$\mathbf{X}$ classification not meaningful

\section{Further information}

German codes and assessments of threat and regeneration ability are according to the National Red Data Book of Biotopes (Riecken et al., 1994). The trilateral approach, dealing with one specific natural region, made it possible and necessary to include some specific threatened subtypes of biotopes. They have been listed in addition to the lists of the National German Red Book.

\section{The EEC Habitats Directive Code}

The habitats directive (Council Directive 92/43/EEC of 21st May 1992 on the conservation of natural habitats and of wild fauna and flora) aims at a European network of pro- 
tected sites of Community importance called NATURA 2000. In Annex I natural habitat types are listed "whose conservation requires the designation of special areas of conservation ". To facilitate the implementation of this Directive and to give transparency for political decisions and in management plans of the Wadden Sea Area, the officially used codes of the Standard Data Entry Form (Doc. Habitats 94/4, Commission of the EEC) are given in this column.

": An asterisk refers to "priority “ habitats with "particular responsibility for their conservation" according to Annex I of the Habitats Directive.

\section{Main Threat Factors}

Under this heading a rough indication of the main negative impacts on biotope complexes and biotopes is given, using a system worked out by Ole Norden, Ministry of Environment, Copenhagen (Denmark). A different system from that devised for the red lists of species was necessary to meet the special needs involved in an assessment of the biotopes.

Biotope loss (permanent, irreversible: HL)

HLB Construction, dredging, dumping

HLM Mineral extraction (prospecting, mining, dredging)

HLW Water regulation (land reclamation, drainage, coastal defence, dyking)

Biotope change (semi-permanent, reversible: $\mathrm{HC}$ )

HCA Agriculture (intensive, changing, land reclamation, stop of traditional farming)

$\mathrm{HCB}$ Construction, dredging, dumping

HCC Climate change (largely irreversible to man)

HCE Eutrophication (fertilization, sewage, combustion)

HCF Fishing

HCG Wear (traffic, tourism)

HCM Mineral extraction

HCP Pollution (non-eutrophication) of air, earth and water (pesticides, waste disposal, sewage, combustion)

HCT Forestry

HCW Water regulation (drainage, rerouting, extraction)

Biotope disturbance (temporary: HD)

HDA Agriculture, forestry

HDB Construction, dredging, dumping, mineral extraction

HDF Fishing

Specimen loss (SL)

SLC Displacement, competition, disease, parasites

SLE Exploitation

SLP Pest control

SLT Traffic

Specimen disturbance (SD)

SDR Recreation (hunting, tourism, sports)

SDT Traffic 
Acknowledgements: Gratitude should be expressed to D. Boedeker, BfN INA Insel Vilm for a preliminary translation of the German biotope definitions, H. v. Nordheim (BfN, INA Insel Vilm), U. Riecken (BfN, Bonn), B. Reineking (CWSS, Wilhelmshaven), Dr. H. Farke (Wadden Sea National Park of Lower Saxony), D. Fleet (Wadden Sea National Park of Schleswig-Holstein), J. Thissen (National Reference Centre for Nature Management, Wageningen) for critical discussion of the manuscript. O. Norden Andersen, Copenhagen, was so kind as to provide a suitable classification of the main threat factors.

\section{REFERENCES}

Blab, J., Riecken, U. \& A. Ssymank, 1995. Proposal on a criteria system for a National Red Data Book of Biotopes. - Landscape Ecol. 10,43-50.

Dijkema, K. S. \& W. J. Wolff (Eds), 1983. Flora and vegetation of the Wadden Sea islands and coastal areas. In: Ecology of the Wadden Sea. Ed. by W. J. Wolff. Balkema, Rotterdam, 3, 9/1-9/413.

Dijkema, K. S., 1989. Habitats of the Netherlands, German and Danish Wadden Sea. Research Institute for Nature Management, Texel, 24 maps, $30 \mathrm{pp}$.

Leerdam, A. van, Wassen, M. J. \& N. Dankers, 1993. Onderzoek nagenoeg-natuurlijke referentieecosystemen. Rijksuniversiteit, Utrecht, $84 \mathrm{pp}$.

Riecken, U., Ries, U. \& A. Ssymank, 1994. Rote Liste der Biotoptypen der Bundesrepublik Deutschland. SchrReihe Landschaftspfl. Natursch. 41, $184 \mathrm{pp}$.

Westhoff, V., Hobom, C. \& J. H. J. Schaminee, 1993. Rote Liste der Pflanzengesellschaften des Naturraums Wattenmeer unter Berücksichtigung der ungefährdeten Vegetationseinheiten. - Tuexenia $13,109-140$.

\section{RED LIST OF BIOTOPES AND BIOTOPE COMPLEXES OF THE WADDEN SEA AREA ${ }^{\circ}$}

\section{0 - Completely destroyed:}

sublittoral oyster reefs

Code Type

03.02 .08

B

\section{1 - Threatened by complete destruction:}

estuaries (natural \& seminatural)

migrating islands

sheltered bays (red list category 1-2)

dune - tidal flats transition zone

mainland saltmarsh complex, natural

pleistocene - tidal flats transition zone

Benthic zone, muddy and sandy bottoms, rich in macrophytes

bogs in tidal erosion (e.g. Sehestedter Moor)

brackish saltmarsh of estuaries

brackish tidal flats of estuaries

coastal lake

freshwater tidal flat of estuaries

$\begin{array}{ll} & \text { L } \\ & \text { L } \\ & \text { L } \\ \text { C3.01 } & \text { C } \\ \text { C1.02 } & \text { C } \\ \text { C3.02 } & \text { C } \\ 03.02 .05 & \text { B } \\ 05.02 .04 & \text { B } \\ 07.06 & \text { B } \\ 05.01 .05 & \text { B } \\ 09.06 & \text { B } \\ 05.01 .06 & \text { B }\end{array}$

\footnotetext{
- Note that types that are threatened in only one subregion are not included because according to the agreement (see 'Introduction') the overall evaluation was only given if at least two regional evaluations were present. Types: L: Landscape complex; C: Biotope complex; B: Biotope.
} 
lower saltmarshes, natural or seminatural

07.01 .01

sublittoral sabellaria reefs

03.02 .09

subtidal seagrass beds

03.02.05.01

upper saltmarshes, natural or seminatural

07.02 .01

\section{2 - Heavily endangered:}

natural complexes of tidal flats

slufter (dune valleys in open connection to the sea)

A3

C1.03

C

washover

C3.03

C

benthic zone, muddy and sandy bottoms with macrophytes

03.02.05.02

C

other than seagrass

benthic zone, stony and hard bottoms, few macrophytes

$03.02 .04 \quad$ B

benthic zone, stony and hard bottoms, rich in macrophytes

03.02 .06

$\mathrm{B}$

brackish and salt water reed marsh

07.04

dune brooks

(23.01)

B

eulittoral (old) blue mussel beds

green beach (Strandwiese)

05.01 .07

07.03

grey dune grassland

10.03

05.02 .01

05.01 .01

10.07

11.03

03.02 .07

05.02 .02

10.05

B

mud flats, free of vegetation

natural shifting dune

pleistocene cliffs

sublittoral (old) blue mussel beds

tidal flats with saltwort stands (Salicornia)

wet dune valleys (incl. coastal fens)

$\begin{array}{ll}\text { A3.03 } & \text { C } \\ \text { A3.02 } & \text { C } \\ \text { C1.01 } & \text { C } \\ \text { A3.01 } & \text { C } \\ 03.02 & \text { B } \\ 05.01 .03 .01 & \text { B } \\ 05.01 .02 & \text { B } \\ 03.01 & \text { B } \\ 05.03 .02 & \text { B } \\ 10.01 & \text { B } \\ 09.01 & \text { B } \\ 05.01 .03 & \text { B } \\ 09.02 & \text { B } \\ 05.03 .01 & \text { B } \\ 07.02 .02 & \text { B } \\ 10.02 & \text { B }\end{array}$

\section{3 - Endangered:}

complete gully system

ebb delta

island saltmarsh complex

tidal divide

benthic zone of the coastal water

flat sandy areas, free of vegetation

mixed flats, free of vegetation

pelagic zone of the coastal water

'priels' and gullies, dry at low tide

primary dunes

sand bank and sands of the backshore

sand flats, free of vegetation

sandy beach

tidal gullies, permanently submerged

upper saltmarshes, anthropozoogenic

white dunes

10.02 
LIST OF THREATENED BIOTOPES AND BIOTOPE COMPLEXES OF THE WADDEN SEA AREA

\begin{tabular}{|c|c|c|c|c|c|c|c|c|c|c|c|c|c|}
\hline \multicolumn{14}{|c|}{ Part I: Biotope-Complex types } \\
\hline \multirow{2}{*}{\multicolumn{2}{|c|}{ Code: }} & \multirow{3}{*}{ Biotope type } & \multirow{3}{*}{ OE } & \multicolumn{6}{|c|}{$\begin{array}{c}\text { Status of threat in the } \\
\text { subregions of the } \\
\text { Wadden Sea Area }\end{array}$} & \multirow{3}{*}{ RE } & \multirow{3}{*}{$\begin{array}{c}\text { Main biotope } \\
\text { types }\end{array}$} & \multirow{3}{*}{$\begin{array}{l}\text { Main } \\
\text { Threats }\end{array}$} & \multirow{3}{*}{$\begin{array}{l}\text { Habitat } \\
\text { Directive }\end{array}$} \\
\hline & & & & \multicolumn{2}{|c|}{ NL } & \multicolumn{2}{|c|}{ D } & \multicolumn{2}{|c|}{ DK } & & & & \\
\hline (D) & $(\mathrm{NL})$ & & & $\mathrm{DE}$ & QU & DE & QU & $\mathrm{DE}$ & $\mathrm{QU}$ & & & & \\
\hline \multicolumn{14}{|c|}{ Complex functional landscape units: } \\
\hline & 11 & Migrating islands & 1 & 1 & 1 & 1 & 1 & & & S & $\mathrm{A} 3, \mathrm{C} 1, \mathrm{C} 3$ & $\begin{array}{c}\text { HLW (coastal } \\
\text { protection) }\end{array}$ & partly incl. \\
\hline & 13 & Sheltered bays & $1-2$ & 1 & 2 & 1 & 2 & & & $B$ & $A 2, A 3, C_{1}$ & $\begin{array}{c}\text { HLW } \\
\text { (reclamation) }\end{array}$ & 1160 \\
\hline & 14 & $\begin{array}{l}\text { Estuaries } \\
\text { (natural and seminatural) }\end{array}$ & 1 & 0 & 1 & 1 & 1 & & & s & $\begin{array}{c}\mathrm{A} 2, \mathrm{A3}, \mathrm{C} 1 \\
\mathrm{C} 3\end{array}$ & HLW, HCP & 1130 \\
\hline \multicolumn{14}{|c|}{ Biotope complexes: } \\
\hline A2 & & $\begin{array}{l}\text { Natural coastal sea } \\
\text { complexes of the North Sea }\end{array}$ & & & & * & 3 & & & & $\begin{array}{l}03.01,03.02 \\
\text { all subtypes }\end{array}$ & $\begin{array}{l}\text { HCB, HCE, } \\
\text { HCF, HCP. } \\
\text { HLM }\end{array}$ & partly incl. \\
\hline$A 3$ & 6 & $\begin{array}{l}\text { Natural complexes of tidal } \\
\text { flats }\end{array}$ & 2 & * & 2 & * & 2 & & & s & & $\begin{array}{l}\text { HCP, SLE, } \\
\text { HCF, HDF }\end{array}$ & partly incl. \\
\hline A3.01 & 7 & Tidal divide & 3 & • & 3 & * & 3 & & & B & \begin{tabular}{|c|}
$05.01 .01-.03$ \\
05.01 .07 \\
09.01
\end{tabular} & $\begin{array}{l}\text { SDR, SLE, } \\
\text { HCF, HDF }\end{array}$ & partly incl. \\
\hline$A 3.02$ & 8 & Ebb delta & 3 & $P$ & 3 & $*$ & 3 & & & B & $\begin{array}{c}05.01 .01-.03 \\
05.03 \\
\end{array}$ & HLB & 1110 \\
\hline A3.03 & 5 & Complete gully system & 3 & * & 3 & * & 3 & & & B-S & $\begin{array}{c}03,05 \\
\text { esp. } 05.03\end{array}$ & $\begin{array}{l}\text { HLB, HCF, } \\
\text { HDF }\end{array}$ & partly incl. \\
\hline $\mathrm{CH}$ & & $\begin{array}{l}\text { Saltmarsh complexes } \\
\text { (natural and seminatural) }\end{array}$ & & & & 2 & $1-2$ & & & B-S & $\begin{array}{r}07,05,09 \\
10.01-10.03 \\
\end{array}$ & & partly incl. \\
\hline C1.01 & 10.2 & Island saltmarsh complex & 3 & * & 3 & 3 & 3 & & & B & \begin{tabular}{|c|} 
07.01.01 \\
07.02 .01 \\
05.01.01 \\
05.02. 05.03
\end{tabular} & $\begin{array}{l}\text { HDA, HLW, } \\
\text { HCA }\end{array}$ & partly incl. \\
\hline C1.02 & 12.1 & $\begin{array}{l}\text { Mainland saltmarsh } \\
\text { complex, natural }\end{array}$ & 1 & 0 & & 1 & 1 & & & S & \begin{tabular}{|c|}
$07.05,09$ \\
10.01 \\
esp. 07.01 .01 \\
07.02 .01 \\
\end{tabular} & $\begin{array}{l}\text { HDA, HCA, } \\
\text { HCC, SDR }\end{array}$ & partly incl. \\
\hline$C 1.03$ & $\begin{array}{c}9.1 \\
23\end{array}$ & $\begin{array}{l}\text { Slufter } \\
\text { (dune valleys in open } \\
\text { connection to North Sea) }\end{array}$ & 2 & 2 & 2 & $p$ & 2 & & & B & $\begin{array}{c}10.01-10.03 \\
07,05\end{array}$ & HLW & partly incl. \\
\hline $\mathrm{C} 3$ & & $\begin{array}{l}\text { Sand coast complexes } \\
\text { (natural) }\end{array}$ & & & & * & $1-2$ & & & K & $\begin{array}{l}05,09,10 \\
11.03\end{array}$ & & partly incl. \\
\hline C3.01 & 12.3 & $\begin{array}{l}\text { Dune-tidal flats transition } \\
\text { zone }\end{array}$ & 1 & 1 & 1 & 1 & 2 & & & 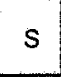 & $05,09,10$ & $\begin{array}{c}\text { HLW (coastal } \\
\text { protection) }\end{array}$ & partly incl. \\
\hline
\end{tabular}




\begin{tabular}{|c|c|c|c|c|c|c|c|c|c|c|c|c|c|}
\hline \multicolumn{14}{|c|}{ Part I: Biotope-Complex types } \\
\hline \multirow{2}{*}{\multicolumn{2}{|c|}{ Code: }} & \multirow{3}{*}{ Biotope type } & \multirow{3}{*}{ OE } & \multicolumn{6}{|c|}{$\begin{array}{l}\text { Status of threat in the } \\
\text { subregions of the } \\
\text { Wadden Sea Area }\end{array}$} & \multirow{3}{*}{ RE } & \multirow{3}{*}{$\begin{array}{c}\text { Main biotope } \\
\text { types }\end{array}$} & \multirow{3}{*}{$\begin{array}{l}\text { Main } \\
\text { Threats }\end{array}$} & \multirow{3}{*}{$\begin{array}{l}\text { Habitat } \\
\text { Directive }\end{array}$} \\
\hline & & & & \multicolumn{2}{|c|}{$\mathrm{NL}$} & \multicolumn{2}{|c|}{$D$} & \multicolumn{2}{|c|}{ DK } & & & & \\
\hline (D) & $(\mathrm{NL})$ & & & $\mathrm{DE}$ & QU & DE & QU & $\mathrm{DE}$ & QU & & & & \\
\hline C3.02 & 12.2 & $\begin{array}{l}\text { Pleistocene- tidal flats } \\
\text { transition zone }\end{array}$ & 1 & 0 & & 1 & 1 & & & S-K & 09,05 & $\begin{array}{c}\text { HLW (coastal } \\
\text { protection) }\end{array}$ & partly incl \\
\hline c3.03 & 9.2 & "Washover" & 2 & 2 & 2 & - & - & & & $B$ & 09,10 & $\begin{array}{c}\text { HLW (coastal } \\
\text { protection) }\end{array}$ & partly incl \\
\hline
\end{tabular}

\begin{tabular}{|c|c|c|c|c|c|c|c|c|c|c|c|c|}
\hline \multicolumn{13}{|c|}{ Part II: Biotope types } \\
\hline \multirow{2}{*}{\multicolumn{2}{|c|}{ Code: }} & \multirow{3}{*}{ Biotope type } & \multirow{3}{*}{ OE } & \multicolumn{6}{|c|}{$\begin{array}{l}\text { Status of threat in the } \\
\text { subregions of the } \\
\text { Wadden Sea Area }\end{array}$} & \multirow{3}{*}{ RE } & \multirow{3}{*}{$\begin{array}{l}\text { Main } \\
\text { Threats }\end{array}$} & \multirow{3}{*}{$\begin{array}{c}\text { Habitat } \\
\text { Directive } \\
\text { Codes of EEC }\end{array}$} \\
\hline & & & & \multicolumn{2}{|c|}{ NL } & \multicolumn{2}{|c|}{$\mathrm{D}$} & \multicolumn{2}{|c|}{ DK } & & & \\
\hline$(\mathrm{D})^{1}$ & $(\mathrm{NL})$ & & & $D E$ & QU & $D E$ & QU & DE & QU & & & \\
\hline \multicolumn{13}{|c|}{ Coastal Water } \\
\hline 03.01 & 1 & Pelagic zone of the coastal water & 3 & * & 3 & * & 3 & & & B & $\begin{array}{c}\text { HCP, HCE, } \\
\text { HCF }\end{array}$ & \\
\hline 03.02 & 2 & Benthic zone of the coastal water & 3 & $*$ & 3 & * & * & & & $B$ & & \\
\hline 03.02 .01 & & $\begin{array}{l}\text { Benthic zone, muddy bottom, } \\
\text { few macrophytes }\end{array}$ & & & & * & 2 & & & & HDF, HCE & \\
\hline 03.02 .02 & & $\begin{array}{l}\text { Benthic zone, sandy bottom } \\
\text { (fine-middle sand), } \\
\text { few macrophytes }\end{array}$ & & & & * & 3 & & & & HDF, HCP & $(1110)$ \\
\hline 0302.03 & & $\begin{array}{l}\text { Benthic zone, coarse sand, } \\
\text { gravel and shell bottoms, } \\
\text { few macrophytes }\end{array}$ & & & & * & 3 & & & & $\begin{array}{c}\mathrm{HCM}, \mathrm{HLM}, \\
\mathrm{HCP}\end{array}$ & \\
\hline 03.02 .04 & 20 & $\begin{array}{l}\text { Benthic zone, stony and hard } \\
\text { bottoms, few macrophytes }\end{array}$ & $2-3$ & 2 & 2 & 3 & 3 & & & s & $\begin{array}{c}\text { HLM, HDF, } \\
\text { HCP }\end{array}$ & \\
\hline 03.02 .05 & 17.52 & $\begin{array}{l}\text { Benthic zone, muddy and sandy } \\
\text { bottoms, rich in macrophytes }\end{array}$ & 1 & 0 & & 2 & 2 & & & $\mathrm{~B}$ & HCE, HDF & \\
\hline 03.02 .05 .01 & & Subtidal seagrass beds & 1 & 0 & & 2 & 2 & & & $\mathrm{~K}$ & $\begin{array}{c}\text { HCE, HCP. } \\
\text { HDF }\end{array}$ & partly incl. \\
\hline 03.02 .05 .02 & & $\begin{array}{l}\text { Benthic zone, muddy and sandy } \\
\text { bottoms with other macrophytes }\end{array}$ & 2 & & & 2 & 2 & & & B & $\begin{array}{c}\text { HCE, HCP. } \\
\text { HDF }\end{array}$ & \\
\hline 03.02 .06 & 20 & $\begin{array}{l}\text { Benthic zone, stony and hard } \\
\text { bottoms, rich in macrophytes, } \\
\text { incl. artificial substrates }\end{array}$ & $2-3$ & 2 & 2 & 3 & 3 & & & B-S & $\begin{array}{l}\text { HLM, HDF, } \\
\text { HCE }\end{array}$ & \\
\hline 03.02 .07 & 17.1 & $\begin{array}{l}\text { Sublittoral (old) blue mussel } \\
\text { beds }\end{array}$ & 2 & 1 & 1 & 3 & 3 & & & $S$ & $\mathrm{HCF}, \mathrm{HCP}$ & 1170 \\
\hline 03.02 .08 & 17.2 & Sublittoral oyster reefs & 0 & 0 & & 0 & & & & $K$ & HLM, HCP & 1170 \\
\hline 03.02 .09 & 17.3 & Sublittoral sabellaria reefs & 1 & 0 & & 2 & 1 & & & s & $\mathrm{HCF}, \mathrm{HCP}$ & 1170 \\
\hline
\end{tabular}




\begin{tabular}{|c|c|c|c|c|c|c|c|c|c|c|c|c|}
\hline \multicolumn{13}{|c|}{ Part II: Biotope types } \\
\hline \multirow{2}{*}{\multicolumn{2}{|c|}{ Code: }} & \multirow{3}{*}{ Biotope type } & \multirow{3}{*}{ OE } & \multicolumn{6}{|c|}{$\begin{array}{c}\text { Status of threat in the } \\
\text { subregions of the } \\
\text { Wadden Sea Area }\end{array}$} & \multirow{3}{*}{ RE } & \multirow{3}{*}{$\begin{array}{l}\text { Main } \\
\text { Threats }\end{array}$} & \multirow{3}{*}{$\begin{array}{c}\text { Habitat } \\
\text { Directive } \\
\text { Codes of EEC }\end{array}$} \\
\hline & & & & \multicolumn{2}{|c|}{ NL } & \multicolumn{2}{|c|}{$D$} & \multicolumn{2}{|c|}{ DK } & & & \\
\hline$(\mathrm{D})^{1}$ & $(\mathrm{NL})$ & & & $\mathrm{DE}$ & QU & $D E$ & QU & DE & QU & & & \\
\hline 03.02 .10 & & $\begin{array}{l}\text { "Seamoss"-stands (Sertularia, } \\
\text { Hydraimannia) }\end{array}$ & & & & 2 & 2 & & & B & HCF. HCP & \\
\hline 03.09 & & Artificial benthic hard substrates & 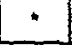 & $*$ & 3 & * & $\dot{-}$ & & & $x$ & & \\
\hline \multicolumn{13}{|l|}{ Tidal flats } \\
\hline 05.01 & 6 & Tidal flats free of vegetation & & & 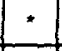 & 2 & & & & $S$ & & \\
\hline 05.01 .01 & 6 & Mud flats, free of vegetation & 2 & * & 2 & 3 & 2 & & & $s$ & HCF. SDR & 1140 \\
\hline 05.07 .02 & 6 & Mixed flats, free of vegetation & 3 & $\dot{.}$ & 2 & 3 & 3 & & & $\mathrm{~s}$ & HCF, SDR & 1140 \\
\hline 05.01 .03 & $6 / 17.4$ & Sand flats, free of vegetation & 3 & 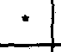 & 2 & 3 & 3 & & & & & 1140 \\
\hline 05.01 .03 .01 & 6 & $\begin{array}{l}\text { Flat sandy areas, free of } \\
\text { vegetation }\end{array}$ & 3 & * & 2 & 3 & 3 & & & $s$ & HCF, SDR & 1140 \\
\hline 05.01 .03 .02 & & "Farbstreifen"-sand flat & & & & 1 & 2 & & & $k$ & & 1140 \\
\hline 05.01 .03 .03 & & Sandbank (eulittoral zone) & & & & 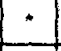 & $2-3$ & & & $\mathrm{~B}$ & & 1140 \\
\hline 05.01 .05 & 15 & Brackish tidal flats of estuaries & 1 & 0 & & 2 & 2 & & & B & $\begin{array}{c}\text { HCE, HCA, } \\
\text { HLB, HLW, } \\
\text { HCP }\end{array}$ & 1130 \\
\hline 05.01 .06 & 16 & Freshwater tidal flat of estuaries & 1 & 0 & & 2 & 2 & & & $s$ & $\begin{array}{l}\text { HCE, HCA, } \\
\text { HLB, HLW, } \\
\text { HCP }\end{array}$ & 1130 \\
\hline 05.0107 & 17.1 & Eulittoral (old) blue mussel beds & 2 & 1 & 1 & 3 & $2-3$ & & & $S$ & $\mathrm{HCF}, \mathrm{HCP}$ & 1170 \\
\hline 05.02 & & \multicolumn{11}{|l|}{ Tidal flats with vegetation } \\
\hline 05.02 .01 & 17.51 & Intertidal seagrass beds & 2 & 2 & 3 & 2 & 2 & & & $\mathrm{~K}$ & $\mathrm{HCF}, \mathrm{HCE}$ & partly incl. \\
\hline 05.02 .02 & & $\begin{array}{l}\text { Tidal flats with saltwort stands } \\
\text { (Salicornia) }\end{array}$ & & . & & 2 & 3 & & & B & & 1310 \\
\hline 05.02 .03 & & $\begin{array}{l}\text { Tidal flats with Spartina anglica } \\
\text { stands }\end{array}$ & 2 & - & & * & * & & & $x$ & & 1320 \\
\hline 05.02 .04 & & $\begin{array}{l}\text { Bogs in tidal erosion (e.g. } \\
\text { Sehestedter Moor) }\end{array}$ & 1 & & & 1 & 1 & & & $N$ & $\mathrm{HL}$ (natural) & 7110 u.a. \\
\hline 05.03 & & Tidal gullies, priels & & & & & & & & & HCF, HLB & \\
\hline 05.03 .04 & & $\begin{array}{l}\text { Tidal gullies, permanently } \\
\text { submerged }\end{array}$ & 3 & • & 3 & * & 2 & & & $B$ & HCF, HLB & \\
\hline 05.03 .02 & & $\begin{array}{l}\text { 'Priels' and gullies, dry at low } \\
\text { tide }\end{array}$ & 3 & - & 3 & 3 & 3 & & & $B$ & HCF, HLB & . \\
\hline \multicolumn{13}{|c|}{ Saltmarshes and meadows } \\
\hline 07.01 .01 & 10.1 & $\begin{array}{l}\text { Lower saltmarshes, natural or } \\
\text { seminatural }\end{array}$ & 1 & 1 & i & $1-2$ & 2 & & & $S$ & HLW & 1330 \\
\hline 07.02 .01 & 10.1 & $\begin{array}{l}\text { Upper saltmarshes, natural or } \\
\text { seminatural }\end{array}$ & 1 & 1 & 1 & $1-2$ & 2 & & & $S$ & HLW & 1330 \\
\hline
\end{tabular}




\begin{tabular}{|c|c|c|c|c|c|c|c|c|c|c|c|c|}
\hline \multicolumn{13}{|c|}{ Part II: Biotope types } \\
\hline \multirow{2}{*}{\multicolumn{2}{|c|}{ Code: }} & \multirow{3}{*}{ Biotope type } & \multirow{3}{*}{ OE } & \multicolumn{6}{|c|}{$\begin{array}{c}\text { Status of threat in the } \\
\text { subregions of the } \\
\text { Wadden Sea Area }\end{array}$} & \multirow{3}{*}{ RE } & \multirow{3}{*}{$\begin{array}{c}\text { Main } \\
\text { Threats }\end{array}$} & \multirow{3}{*}{$\begin{array}{c}\text { Habitat } \\
\text { Directive } \\
\text { Codes of EEC }\end{array}$} \\
\hline & & & & \multicolumn{2}{|c|}{ NL } & \multicolumn{2}{|c|}{$D$} & \multicolumn{2}{|c|}{ DK } & & & \\
\hline (D) ${ }^{1}$ & $(\mathrm{NL})$ & & & DE & QU & $D E$ & QU & $D E$ & QU & & & \\
\hline 07.02 .02 & 10.3 & $\begin{array}{l}\text { Upper saltmarshes, } \\
\text { anthropozoogenic }\end{array}$ & 3 & 3 & 3 & $2-3$ & 3 & & & $x$ & HCA, HLW & 1330 \\
\hline 07.03 & 10.4 & Green beach (Strandwiese) & 2 & 2 & 2 & 1 & 2 & & & s & SDR, HLW & 1330,2110 \\
\hline 07.04 & & $\begin{array}{l}\text { Brackish and salt water reed } \\
\text { marsh }\end{array}$ & 2 & 1 & 2 & 2 & 2 & & & B & $\begin{array}{c}\text { HDA, HCA, } \\
\text { HLW }\end{array}$ & \\
\hline 07.05 & & Brackish tall herb stands & & & & 2 & 2 & & & $\mathrm{~B}$ & SDR, HLW & \\
\hline 07.06 & 10.1 & Brackish saltmarsh of estuaries & 1 & 0 & & 2 & 2 & & & B & SDR, HLW & 1130 \\
\hline \multicolumn{13}{|c|}{ Sands and beaches } \\
\hline 09.01 & 3 & $\begin{array}{l}\text { Sand bank and sands of the } \\
\text { backshore }\end{array}$ & 3 & * & 3 & * & 3 & & & $\mathrm{~B}$ & SDR, HLW & partly incl. \\
\hline 09.02 & 4 & Sandy beach & 3 & $\mathrm{P}$ & 3 & * & $2-3$ & & & $B$ & SDR, HLW & partly incl. \\
\hline 09.05 & & Beach ridge (Strandwall) & & & & 2 & 2 & & & $k$ & & partly incl. \\
\hline 09.06 & 18 & Coastal lake & 1 & 1 & 2 & 1 & 2 & & & $S$ & HLW & ${ }^{*} 1150$ \\
\hline \multicolumn{13}{|c|}{ Coastal dunes } \\
\hline 10.01 & & Primary dunes & 3 & 3 & 3 & 3 & 2 & & & $B$ & HCG, SDR & 2110 \\
\hline 10.02 & 21 & White dunes & 3 & * & * & 3 & 2 & & & $\mathrm{~S}$ & $\begin{array}{c}\text { HLW } \\
\text { (coastal } \\
\text { protection). } \\
\text { HCG }\end{array}$ & 2120 \\
\hline 10.03 & (24) & Grey dune grassland & 2 & 3 & 2 & 3 & 2 & & & $\mathrm{~S}$ & $\begin{array}{c}\text { HLW } \\
\text { (coastal } \\
\text { protection), } \\
\text { HCG }\end{array}$ & $\begin{array}{l}* 2130 \\
2320\end{array}$ \\
\hline 10.04 .01 & & $\begin{array}{l}\text { Dunes and coastal heath with } \\
\text { Empetrum nignum }\end{array}$ & & & & 2 & $2-3$ & & & $\mathrm{~S}$ & HLW, HCG & $* 2140$ \\
\hline 10.04 .02 & & Dune heath with Calluna vulgaris & & & & $2-3$ & 2 & & & $\mathrm{~s}$ & HLW, HCG & \\
\hline 10.05 & 22,25 & $\begin{array}{l}\text { Wet dune valleys } \\
\text { (incl. coastal fens) }\end{array}$ & 2 & * & 3 & 2 & $1-2$ & & & $\mathrm{~S}$ & HLW, HCG & 2190 \\
\hline$(23.01)$ & 26 & Dune brooks & 2 & 2 & 2 & $?$ & & & & s & HLW, HCG & 2190 \\
\hline 10.06 & & Dune scrub (natural) & & & & 3 & 2 & & & & SLC, HCG & 2160,2170 \\
\hline 10.07 & 28 & Natural shifting dune & 2 & 2 & 2 & 1 & 3 & & & S & $\begin{array}{c}\text { HLW } \\
\text { (coastal } \\
\text { protection), } \\
\text { HCG }\end{array}$ & \\
\hline 11.03 & $12: 2$ & Pleistocene cliffs & 2 & 0 & & 2 & 3 & & & & $\begin{array}{c}\text { HLB, HLW, } \\
\text { HCG }\end{array}$ & 1230 \\
\hline
\end{tabular}

\footnotetext{
1 Codes according to Riecken et al., 1994.
} 